UDC 628.194: 628.1

DOI: $10.21668 /$ health.risk/2020.2.03.eng

\title{
HYGIENIC ASSESSMENT OF DRINKING WATER FROM UNDERGROUND WATER SOURCES TAKEN FROM CENTRALIZED WATER SUPPLY SYSTEMS ON ISLAND RUSSKIY
}

\author{
V.D. Bogdanova ${ }^{1,2}$, P.F. Kiku ${ }^{1}$, L.V. Kislitsyna ${ }^{2}$ \\ ${ }^{1}$ School of Biomedicine of Far Eastern Federal University, Bld. 25, FEFU Campus, Ajax Bay, Russkiy Island, \\ 690922, Russian Federation \\ ${ }^{2}$ Center for Hygiene and Epidemiology in Primorye, 36 Utkinskaya Str., Vladivostok, 690091, Russian Federation
}

\begin{abstract}
Drinking water is a leading environmental and hygienic factor that influences population health as it tends to contain a lot of chemicals, both natural and anthropogenic in their origin.

Our research goal was to hygienically assess drinking water from underground water sources taken from centralized water supply systems on Island Russiky.

Research object. We hygienically assessed quality of water supply on Island Russkiy (Primorye) in 2017-2019 as per 33 sanitary-chemical and 3 microbiological parameters at three stages: water from underground sources (120 samples); water at pump stations (138 samples); water taken from distribution network (204 samples).

Data and methods. The first stage in hygienic assessment of drinking water was performed as per methodical guidelines provided by F.F. Erisman's Federal Scientific Center for Hygiene «Assessment of sanitary-epidemiologic reliability of centralized drinking water supply systems» (MG 2.1.4-2370-08). The second stage involved calculating reflex-olfactor, chronic non-carcinogenic and carcinogenic effects and integral assessment of drinking water taken from centralized water supply systems as per chemical safety parameters (MG 2.1.4.0032-11).

Basic results. We detected that drinking water quality most significantly deteriorated as per its microbiological and organoleptic parameters during transportation, and it made the greatest contribution into sanitary-epidemiologic ill-being of centralized drinking water supply systems. We revealed that non-carcinogenic risks and reflex-olfactor impacts exceeded their acceptable levels. Our analysis also revealed that physiologically insufficient iron contents and water turbidity were priority factors that predetermined poor quality of drinking water. Chemical structure of drinking water didn't cause any significant threats for population health; however, it is necessary to reconstruct water supply systems and eliminate deficiency of macro- and micro-elements in drinking water due to additional sources of their supply.

Key words: underground source, pump stations, distribution network, iron, turbidity, reliability of water supply systems, Island Russkiy, risk assessment.
\end{abstract}

The impact of environmental and hygienic factors of habitat on population health in the current conditions of the society development governs the need to improve the forms and methods of risk assessment [1]. Establishing causal links between public health and exposure to environmental factors is the basis for social and hygienic monitoring (SHM) - a sys- tem of continuous monitoring and assessment of environmental factors, forecasting the development of adverse effects and decisionmaking to reduce risks to public health [2]. Identification of patterns in distributing the resulting risk by time and territory gives an opportunity to accumulate preventive activities before the rise of morbidity in the terri-

(C) Bogdanova V.D., Kiku P.F., Kislitsyna L.V., 2020

Valeriya D. Bogdanova - post-graduate student at the Department for Public Health and Prevention Medicine, biologist at the Social and Hygienic Monitoring Department (e-mail: ha-lera@mail.ru; tel.: +7 (423) 240-21-85; ORCID: https://orcid.org/0000-0002-5580-5442).

Pavel F. Kiku - Doctor of Medical Sciences, Candidate of Technical Sciences, Director of the Department for Public Health and Prevention Medicine (e-mail: lme@list.ru; tel.: +7 (423) 265-24-24; ORCID: https://orcid.org/0000-0003-3536-8617).

Lidiya V. Kislitsyna - Head of the Social and Hygienic Monitoring Department (e-mail: sgm@fguzpk.ru; tel.: +7 (423) 240-21-85; ORCID: https://orcid.org/0000-0002-4172-609X). 
tory where its occurrence probability is the highest $[3,4]$. At present, such patterns are outlined in the methodology of risk assessment for public health ${ }^{1}$.

The importance of groundwater as a source of drinking water supply has increased in recent years, due to its several advantages over surface sources. Groundwater is not subject to seasonal changes and is reliably protected from pollution in case of anthropogenic disasters. Data from the state report «On the state of sanitary and epidemiological wellbeing in the Russian Federation in 2018» also confirm the high quality of groundwater in comparison with surface sources ${ }^{2}$. During 2013-2018, the share of surface sources in the Russian Federation that do not meet sanitary and epidemiological requirements is at least twice as high as the share of underground sources.

Comparative analysis of water quality from groundwater and surface sources based on microbiological parameters both in the Russian Federation (RF) and in the territory of the Primorskiy Krai (PK), in particular, confirms the best protection of groundwater from living organisms' penetration ${ }^{3}$. However, in terms of sanitary and chemical parameters, the share of unsatisfactory samples taken from the underground sources is higher (2018: RF $25.8 \%$; PK $-18.2 \%$ ) than from the surface sources (2018: RF - $21.6 \%$; PK - $1.1 \%$ ).

The list of sanitary and chemical parameters for drinking water that have a significant impact on public health includes chemicals of both natural and anthropogenic origin. In order to assess the risk of their presence with respect to drinking water, an oral route associated with water supply as drinking water should be chosen as the priority exposure scenario. Methodical guidelines MG 2.1.4.0032-11 serve as a supporting methodology for assessing the risk of chemicals in drinking water to public health ${ }^{4}$. They supplement the guidelines with the criteria for the acceptable risk levels and an algorithm for the formation of an overall or integral assessment of its harmlessness.

Environmental problems are more often addressed in large cities [5]. At the same time, small settlements on the island territories that are part of an urban district, but are remote from the major water supply networks have specific issues, often unrelated to the industrial load, but having a significant impact on public health [6-8]. For example, water supply on Island Russkiy is carried out from the deep well-water intakes, which provide drinking water to small settlements (settlements of Ekipajniy, KET, Shigino, Rynda, Voyevoda, Melkvodniy, Paris, Podnozhye, Tserkovnaya Pad'). The rest of the settlements and objects located on the island are supplied with water from the surface sources. Ekipajniy, KET, Shigino, Rynda are under surveillance within the system of SHM.

Only half of the wells (8 out of 16), where water is taken for Island Russkiy, are not subject to surface contamination. Water distribution networks are $59 \%$ worn- out, their condition requires technical improvement, the condition of water pumping stations - operational ${ }^{5}$.

The purpose of the study is hygienic assessment of drinking water from the under-

${ }^{1}$ R 2.1.10.1920-04. Guidance on Health Risk Assessment under the Exposure of Chemicals Polluting the Environment. In: Yu.A. Rachmanin, G.G. Onishchenko, A.V. Kiselev [et al.] eds. Moscow, Federal Centre of the State Sanitary and Epidemiological Surveillance of the Ministry of Health of Russia, 2004, 143 p. (in Russian).

${ }^{2}$ On the State of Sanitary and Epidemiological Well-being in the Russian Federation in 2018: State report. Moscow, Federal Service for Surveillance over Consumer Rights Protection and Human Wellbeing, 2019, 254 p. (in Russian).

${ }^{3}$ On the Sanitary and Epidemiological situation in Primorskiy Krai in 2018: State report. Vladivostok, for Surveillance over Consumer Rights Protection and Human Wellbeing in Primorskiy Krai, 2019, 343 p. (in Russian).

${ }^{4}$ MG 2.1.4.0032-11.2.1.4. Drinking water and water supply to populated areas. Integrated assessment of drinking water of centralized water supply systems by the indices of chemical harmlessness: Methodical guidelines. Approved by the Chief State Sanitary Doctor of the Russian Federation 31.07.2011. ConsultantPlus. Available at: http://www.consultant.ru/document/cons_doc_LAW_119675/(11.03.2020) (in Russian).

${ }^{5}$ Water supply and disposal plans of the Vladivostok city district for the period 2014-2025: Annex to the Decree of the Vladivostok city administration dated 31.12.2013 N 3899. Garant: Information and Legal support. Available at: http://base.garant.ru/30177683/53f89421bbdaf741eb2d1ecc4ddb4c33/ (11.03.2020) (in Russian). 
ground sources of the centralized water supply systems in Island Russkiy.

To meet this purpose, we set and solved the following tasks:

- to assess drinking water quality and water physiological adequacy (the full-value condition) at all stages of water supply in terms of maximum concentrations of substances divided by the limiting harmful indices;

- to give a qualitative assessment for the ill-being degree of each block on a 4-rank scale with the definition of priority elements characterizing the sanitary-epidemiological reliability of the centralized water supply systems ${ }^{6}$;

- to calculate and assess risks at oral intake of chemicals with drinking water characterized by olfactory-reflexive (organoleptic), non-cancerogenic and carcinogenic effects.

Data and methods. To assess sanitaryepidemiological reliability of the centralized water supply systems, 28 sanitary-chemical and 3 microbiological parameters of drinking water for 2017-2019 were analyzed. Qualitative assessment of the ill-being degree for each block on a 4-rank scale was carried out with the determination of priority elements on the basis of MR 2.1.4.2370-08. Individual factors that form sanitary and epidemiological reliability of the water supply system were identified through $\mathrm{W}$ index. The assessment was carried out by 8 blocks (factors).

Samples were taken at different stages of the water treatment system: in wells, at the outlet of water pumping stations and from the water stand-pipes in Island Russkiy in 4 settlements (Shigino, Rynda, Ekipajniy, KET). Chemical substances concentrations in drinking water taken from the wells and at the outlet of stations were determined by KSUE «Pri- morskiy Vodokanal» (46\% of samples). The enterprise collects, stores, treats and supplies drinking water in the surveyed settlements. Data on the drinking water quality taken from the external water collection facilities (standpipes) at the monitoring points were determined by FSUE «Center for Hygiene and Epidemiology in Primorskiy Krai» (44 \% of samples). The results of 462 drinking water samples were analyzed using the following techniques: microbiological, atomic absorption with flame atomization, gravimetry, titrimetry, potentiometry, fluorimetry, photometry and gas chromatography.

The studied parameters are divided by the Limiting Harmful Index (LHI) according to GN 2.1.5.1315-037 ${ }^{7}$. Epidemiological parameters include total microbial number, total coliform bacteria and thermotolerant coliform bacteria). Sanitary and toxicological indices include nitrates, fluoride ion, arsenic, nickel, lead, cobalt and cadmium. The organoleptic ones include total iron, total manganese, magnesium, color index, turbidity, copper and aluminium. Iron and manganese affect the color of water, magnesium, copper - the offflavour, aluminum - the turbidity. The list of composite indices includes: permanganate oxidation, hydrogen index, total hardness, dry residue, multi-sulfur oil, surfactants, phenolic index, zinc, calcium (optimal value: $60 \mathrm{mg} / \mathrm{l}$ ) .

Carcinogenic, non-carcinogenic and organoleptic risks at the stage of water consumption were calculated to obtain an integral assessment of eventual negative impact of water on public health using MG 2.1.4.0032-11.2.1.4. For the calculation of non-carcinogenic risk from chemical exposure, 18 indices were selected, for carcinogenic risk calculation -7 indices. The initial sampling was added with the

\footnotetext{
${ }^{6}$ MR 2.1.4.2370-08. Drinking water and water supply for residential areas. Assessment of the sanitary-epidemiological reliability of the centralized drinking water supply systems. Approved by the Federal Service for Surveillance over Consumer Rights Protection and Human Wellbeing, Chief State Sanitary Doctor of RF June 16, 2008. CODEX: electronic fund of legal and normative and technical documentation. Available at: http://docs.cntd.ru/document/1200077721 (11.03.2020) (in Russian).

${ }^{7}$ GN 2.1.5.1315-03. Maximum Permissible Concentrations (MPC) of Chemicals in Water of Water Objects of Drinking and Household and Cultural and Social Water Use. CODEX: electronic fund of legal and normative and technical documentation. Available at: http://docs.cntd.ru/document/901862249 (11.03.2020) (in Russian).

${ }^{8}$ Gildenskiold R.S., Yastrebov G.G., Vinokur I.L. Integrated determination of anthropogenic load on water bodies, soil, atmospheric air in residential areas: Methodical guidelines of the State Committee for Environmental Protection of Russia. Moscow, 1996, 35 p. (in Russian).
} 
substances of Hazard Class 1: chloroform (MPC: $0.06 \mathrm{mg} / \mathrm{l}$ ), tetrachloromethane (MPC: $0.002 \mathrm{mg} / \mathrm{l}$ ), bromdichloromethane (MPC: $0.03 \mathrm{mg} / \mathrm{l}$ ), tetrachloroethylene (MPC: $0.005 \mathrm{mg} / \mathrm{l}$ ), and substance of Hazard Class 2: strontium (MPC: $7 \mathrm{mg} / \mathrm{l}$ ). The choice of additional indices is made based on the class of hazard and carcinogenicity, and is relevant for Class 2 water bodies of economic and drinking water supply in the Primorskiy Krai, where disinfection is carried out by chlorination.

Maximum actual concentrations of substances were used to assess the reliability of centralized water supply systems as well as the physiological full-value condition of drinking water. For the integral assessment of water organoleptic properties the maximum parameters of $98 \%$ probability were taken, for the assessment of expected non-cancerogenic and carcinogenic effects - the average annual concentrations of $95 \%$ probability were used.

Carcinogenic risk assessment was performed using the standard values: daily consumption of 2 liters for exposure duration of 30 years and the average human weight in a population of $70 \mathrm{~kg}$.

Results and discussion. Population coverage with the centralized water supply in the settlements of Island Russkiy, according to the data of the last population census in 2010 and the annual data on population using piped water provided by KSUE «Primorskiy Vodokanal» for 2019, is estimated as insufficient $(92 \%$ for permanent residents of the whole Island Russkiy). As a result, the general characteristics of these settlements are estimated as moderate by the scale of sanitary-epidemiological reliability of drinking water supply to population, considering the absence of facts of exceeding the design capacity of water pumping stations and interruptions in drinking water supply $\left(\mathrm{W}_{1}=0.3\right)$.

The water intake facilities studied are operated under the conditions of compliance with the mode of source water sanitary protection zones according to SanPiN 2.1.4.1110-02 (assessed 'satisfactory' for all settlements by the relevant scale, $\left.\mathrm{W}_{2}=0\right)^{9}$. Laboratory control of drinking water conditions is carried out in accordance with SanPiN 2.1.4.1074-01 (assessed 'satisfactory' for all residential locations by the relevant scale, $\left.\mathrm{W}_{7}=0\right)^{10}$.

For ranking the residential settlements, we used rating scales for sanitary-epidemiological condition of underground water supply sources $\left(\mathrm{W}_{3}\right)$, reliability of water treatment $\left(\mathrm{W}_{5}\right)$ and drinking water transportation in centralized water supply systems $\left(\mathrm{W}_{6}\right)$, as well as quality of drinking water from a water-dispensing unit $\left(\mathrm{W}_{8}\right)$ by LHI and physiological full-value condition. The assessment results for sanitary and epidemiological ill-being are presented in points (Table 1).

The assessment of water quality from the underground water supply sources showed that there were no the above-limit values in terms of hygienic standards for sanitary, chemical and epidemiological parameters. All samples were in line with the maximum permissible values. The qualitative characteristics $\left(\mathrm{W}_{3}\right)$ of the assessment scale corresponded to the first rank (permissible level).

The drinking water in all settlements had a lower content of calcium, magnesium and fluoride salts, and was characterized by low mineralization and hardness. All parameters of the drinking water physiological full-value condition were below the optimal values. Consumption of too «soft» drinking water without taking the additional sources of calcium and magnesium may be one of the risk factors for cardiovascular diseases [9-11].

Despite the fact that fluorine is one of the priority components of natural origin with a high probability of detecting the MPCs excess in the territory of the Primorskiy Krai, according to SP 2.1.5.1059-01, the opposite phenomenon was observed in the locations studied. Low fluoride concentrations in drinking

\footnotetext{
${ }^{9}$ SanPiN 2.1.4.1110-02. Sanitary protection zones of water supply sources and drinking water pipelines. Moscow, 2002, 11 p. (in Russian).

${ }^{10}$ SanPiN 2.1.4.1074-01. Drinking water. Hygienic requirements for water quality of centralized drinking water supply systems. Quality control. Moscow, 2001, 62 p. (in Russian).
} 
Table 1

Assessment of sanitary-epidemiological reliability of centralized drinking water supply systems and indices of physiological full-value condition of water mineral composition

\begin{tabular}{|c|c|c|c|c|c|c|c|c|c|c|}
\hline \multirow{2}{*}{ 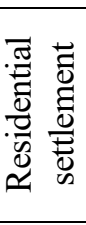 } & \multirow{2}{*}{ 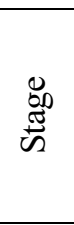 } & \multicolumn{3}{|c|}{$\begin{array}{l}\text { Sanitary and epidemiological reliability } \\
\text { (score in points) }\end{array}$} & \multicolumn{5}{|c|}{$\begin{array}{l}\text { Physiological full-value condition } \\
\text { of water mineral composition } \\
\text { (Cmax, mg/l) }\end{array}$} & \multirow{2}{*}{$\begin{array}{l}\mathrm{Ca}^{2+} / \mathrm{Mg}^{2+} \\
\text { mmole-eqv/l }\end{array}$} \\
\hline & & $\begin{array}{l}\text { Water quality } \\
\text { at certain stages }\end{array}$ & $\mathrm{W}_{6}$ & $\mathrm{~W}_{\mathrm{ov}}$ & $\mathrm{TH}$ & TDS & $\mathrm{F}^{-}$ & $\mathrm{Mg}^{2+}$ & $\mathrm{Ca}^{2+}$ & \\
\hline \multirow{3}{*}{$\stackrel{\sqrt[1]{1}}{\underline{1}}$} & $\mathrm{~W}_{3}$ & 0 (Permissible) & \multirow{3}{*}{$1.05(0.75+0.3)^{* *}$} & \multirow{3}{*}{0.84} & 2.2 & 211.0 & 0.5 & 18.2 & 16.6 & 0.8 \\
\hline & $\mathrm{W}_{5}$ & 0 (Permissible) & & & 2.0 & 205.0 & 0.3 & 10.9 & 21.3 & 1.2 \\
\hline & $\mathrm{W}_{8}$ & $1.65(0.3+0.3+1.05)^{*}$ & & & 1.2 & 94.1 & 0.1 & 9.6 & 25.5 & 2.0 \\
\hline \multirow{3}{*}{ 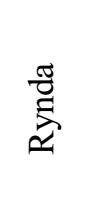 } & $\mathrm{W}_{3}$ & 0 (Permissible) & \multirow{3}{*}{$1.05(0.75+0.3)^{* *}$} & \multirow{3}{*}{0.83} & 2.1 & 221.0 & 0.4 & 13.4 & 18.7 & 1.2 \\
\hline & $\mathrm{W}_{5}$ & 0 (Permissible) & & & 1.8 & 207.0 & 0.2 & 6.1 & 21.6 & 2.6 \\
\hline & $\mathrm{W}_{8}$ & $1.6(0.3+0.25+1.05) *$ & & & 1.1 & 105.5 & 0.2 & 3.8 & 21.3 & 5.4 \\
\hline \multirow{3}{*}{ 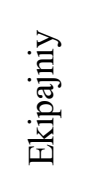 } & $\mathrm{W}_{3}$ & 0 (Permissible) & \multirow{3}{*}{$1.05(0.75+0.3)^{* *}$} & \multirow{3}{*}{0.83} & 2.2 & 187.0 & 0.4 & 14.6 & 17.8 & 1.0 \\
\hline & $\mathrm{W}_{5}$ & 0 (Permissible) & & & 2.2 & 208.0 & 0.3 & 10.3 & 18.0 & 1.5 \\
\hline & $\mathrm{W}_{8}$ & $1.6(0.3+0.25+1.05)^{*}$ & & & 1.1 & 106.3 & 0.2 & 10.1 & 20.0 & 1.7 \\
\hline \multirow{3}{*}{ 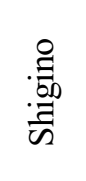 } & $\mathrm{W}_{3}$ & 0 (Permissible) & \multirow{3}{*}{$0.95(0.75+0.2)^{* *}$} & \multirow{3}{*}{0.79} & 1.3 & 105.0 & 0.2 & 4.3 & 18.0 & 2.7 \\
\hline & $\mathrm{W}_{5}$ & 0 (Permissible) & & & 1.6 & 202.0 & 0.2 & 4.9 & 7.5 & 1.0 \\
\hline & $\mathrm{W}_{8}$ & $1.5(0.1+0.35+1.05)^{*}$ & & & 0.9 & 90.5 & 0.2 & 3.6 & 14.5 & 5.0 \\
\hline \multicolumn{5}{|c|}{$\begin{array}{c}\text { Optimal value: MR 2.1.4.2370-08 (TH, TDS, F'), } \\
\text { SanPiN 2.1.4.1116-02 }{ }^{11}\left(\mathrm{Ca}^{2+}, \mathrm{Mg}^{2+}\right)\end{array}$} & $1.5-7$ & $200-500$ & $0.8-1.5$ & $5-65$ & $25-130$ & - \\
\hline
\end{tabular}

Note:

* - organoleptic + physiological full-value condition + microbiological;

** - microbiological + organoleptic (sum of points in terms of LHI);

$* * *-\mathrm{W}_{6}-$ transportation;

$\mathrm{W}_{3}$ - water source quality;

$\mathrm{W}_{5}$ - water treatment (water quality at the pumping station outlet);

$\mathrm{W}_{8}-$ water quality from the distribution network;

$\mathrm{W}_{\mathrm{ov}}$ - overall composite index;

$\mathrm{TH}$ - total hardness;

TDS - total dissolved solids.

water increase the risk of caries development. Calcium along with fluorides is an important protective factor against caries. Their combined protective effect has been proven in several analytical studies ${ }^{12}[12,13]$.

In the studied drinking water samples taken from wells, the ratio of $\mathrm{Ca}^{2+}$ and $\mathrm{Mg}^{2+}$ ion concentrations (expressed in mmol-eq./1) was significantly lower in the three settlements than in drinking water passing through the water supply network. This was due to an increase in soluble calcium compounds and a decrease in the number of magnesium ions during the transportation of water to consumer.

${ }^{11}$ SanPiN 2.1.4.1116-02. Drinking water. Hygienic requirements for the quality of water packaged in containers. Quality control. Moscow, 2002, 22 p. (in Russian).

${ }^{12}$ SanPin 2.1.5.1059-01. Hygienic requirements for groundwater protection against pollution. Moscow, $2001,14 \mathrm{p}$. (in Russian). 
In terms of such indices, as total hardness, total mineralization and fluorine, there was a tendency to decreasing concentrations during transportation through water supply network.

At the water pumping stations outlet, the analysis results for the drinking water samples $\left(\mathrm{W}_{5}\right)$ met hygienic standards which speaks of the proper water treatment and consistency of drinking water composition on the way from the water supply source to the pumping stations and before entering the distribution network. Water treatment improves drinking water quality in terms of such organoleptic indices, as iron and turbidity.

The analysis results for the quality of drinking water taken from the distribution network (stand-pipes) occasionally did not meet hygienic standards for microbiological and organoleptic parameters (in Table 1 these indices are included in the assessment of water quality from the distribution network $-\mathrm{W}_{8}$ ). Physiological deficiency of water, in terms of general mineralization («extremely high» illbeing degree for all locations), overall mineralization and fluoride concentrations («moderate» for one third of locations and «high» - for Shigino settlement) contributed to the sanitary ill-being of the drinking water.

The ill-being degree in terms of microbiological parameters by the scale of sanitaryepidemiological reliability of drinking water transportation in the centralized water supply systems was assessed as «extremely unsatisfactory» ( $>10 \%$ of unsatisfactory samples) for all networks studied. According to organoleptic indices, when calculating the above-limit MPC's values multiplicity factor of the maximum concentrations, the qualitative assessment was defined as «extremely unsatisfactory» for one third of settlements and «moderate» - for Shigino settlement.

The quality parameter of the drinking water from the distribution network $\left(\mathrm{W}_{8}\right)$ by the scale of sanitary and epidemiological ill-being for water was closer to the «high» pollution characteristics (rank $3^{\text {rd }}$ out of 4 possible ones), taking into account the contribution coefficients of each limiting index (overall, organoleptic, sanitary-toxicological, epidemiol- ogical and physiological full-value condition of mineral composition).

Having assessed the sanitary and epidemiological reliability of the drinking water transportation $\left(\mathrm{W}_{6}\right)$, we can speak about the increase in the share of non-standard samples in terms of organoleptic and microbiological LHI. According to the scale of sanitaryepidemiological ill-being of drinking water transportation, the qualitative characteristic of pollution was defined as «moderate» in all residential settlements.

It should be noted a significant increase in maximum concentrations of iron and turbidity of water in the distribution network due to its transportation from the pumping station to the water stand-pipe (Figure).
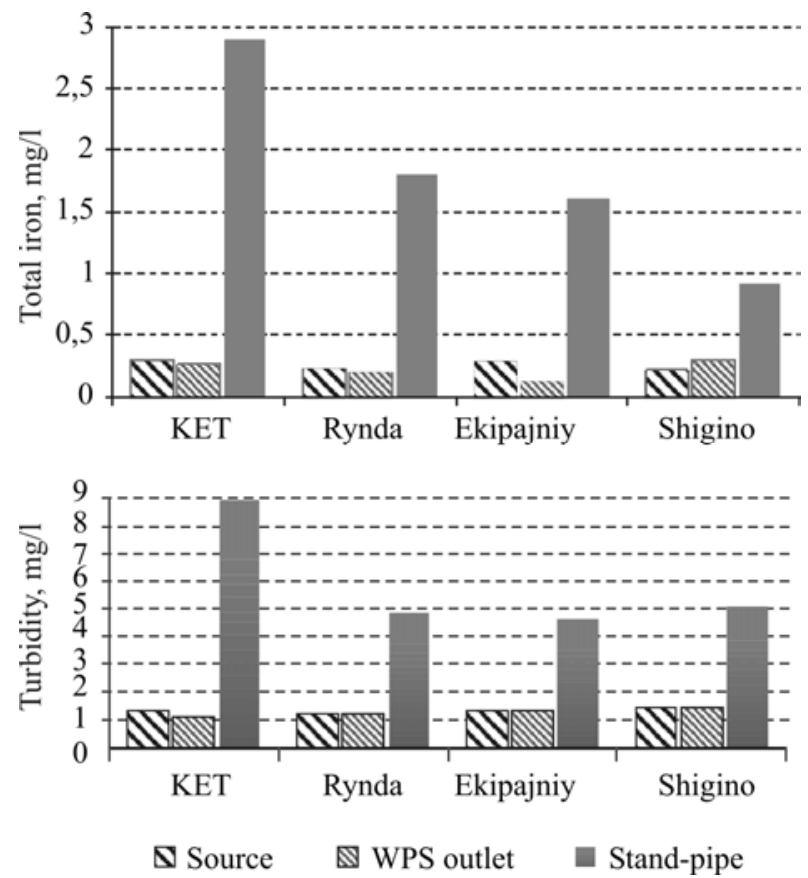

Figure. Concentration of total iron and turbidity in drinking water of the centralized water supply taken from underground sources, at a pumping station and from a distribution network

This pattern was observed not only in the studied locations of the Island Russkiy, but also on other territories of the region, the Russian Federation subjects and beyond [14-18]. Iron content above $1 \mathrm{mg} / 1$ deteriorates organoleptic properties of water, it becomes turbid, colored in yellow-brown color, it has a characteristic metallic flavor, mucus is formed 
on the pipes walls, typical for iron bacteria. Such water has an adverse effect on skin, causing dryness and itching.

In terms of the overall composite index $\left(\mathrm{W}_{\mathrm{ov}}\right)$, the ill-being degree of drinking water supply can be considered as «moderate» $\left(0<\mathrm{W}_{\text {ov }}<1\right)$ in all settlements.

The overall index defined the network in Shigino settlement as the most satisfactory drinking water supply system, despite the fact that drinking water there is the least physiologically full-valued by its mineral composition. As the research results show, microbiological and organoleptic indices make the most significant contribution to the assessment of sanitaryepidemiological reliability of water supply systems in these settlements. As a result, the share of non-standard samples in the distribution network increased compared to those registered at the outlet of the pumping station.

The priority type of impact, when calculating the integral health risk for the population consuming drinking water from the distribution network, is the olfactory-reflex effect, which prevails in all water supply systems under study (Table 2). The leading indicator in assessing the organoleptic effects of exposure to maximum concentrations of $98 \%$ probability of such water consumption is iron in three settlements, and turbidity (Shigino settlement).
The intrinsic uncertainty responsible for reliability and validity of risk assessments at the dose-effect stage is the lack of sensitivity in laboratory techniques for such indicators as aluminium, zinc, multi-sulfur oil, nickel, tetrachloroethylene, tetrachloromethane, arsenic and cadmium. Due to the fact that it was not possible to determine the exact data on these substances actual concentration taking into account the methods used, and thus did not guarantee the calculations objectivity for noncarcinogenic and carcinogenic risks, it was decided not to use them for risk assessment. It should be noted that the established concentrations of these substances at the lower limit of methods sensitivity were the values from $0.001 \mathrm{MPC}$ - for zinc to $0.3 \mathrm{MPC}$ - for tetrachloromethane. According to the uncertainty analysis, the final list of criteria considered in risk assessment is given in Table 3 .

Non-cancerogenic risks did not exceed the acceptable value for certain selected parameters. The total non-cancerogenic risk in drinking water consumption exceeded the permissible level (0.05) in KET settlement due to the unacceptably high concentration of total iron. In the concentrations detected, iron can have an irritating effect on mucous membranes, cause changes in skin, affect hematopoietic and immune systems and peripheral blood parameters.

Table 2

Overall indices for the quality of drinking water from the distribution network

\begin{tabular}{|c|c|c|c|c|}
\hline Residential settlement & Risk type & Value by total score & Risk to acceptable value & Overall index \\
\hline \multirow{3}{*}{ KET } & $\mathrm{OR}$ & 0.70 & 7.04 & \multirow{3}{*}{8.60} \\
\hline & NCR & 0.06 & 1.12 & \\
\hline & $\mathrm{CR}$ & 0.000004 & 0.45 & \\
\hline \multirow{3}{*}{ Rynda } & OR & 0.40 & 3.99 & \multirow{3}{*}{5.13} \\
\hline & NCR & 0.04 & 0.76 & \\
\hline & $\mathrm{CR}$ & 0.000004 & 0.38 & \\
\hline \multirow{3}{*}{ Ekipajniy } & OR & 0.38 & 3.76 & \multirow{3}{*}{5.06} \\
\hline & NCR & 0.04 & 0.82 & \\
\hline & $\mathrm{CR}$ & 0.000005 & 0.47 & \\
\hline \multirow{3}{*}{ Shigino } & OR & 0.13 & 1.25 & \multirow{3}{*}{2.42} \\
\hline & NCR & 0.03 & 0.61 & \\
\hline & $\mathrm{CR}$ & 0.000006 & 0.56 & \\
\hline
\end{tabular}

N o t e s:

OR - organoleptic risk;

$\mathrm{NCR}$ - non-carcinogenic risk;

$\mathrm{CR}$ - carcinogenic risk. 
Table 3

Results of risk assessment by criteria taken into account

\begin{tabular}{|c|c|c|c|c|c|c|c|c|}
\hline \multicolumn{9}{|c|}{ Non-cancerogenic risk assessment results } \\
\hline Criteria taken into account & $\mathrm{C}_{95 \%}$ & $\mathrm{HP}$ & $\mathrm{C}_{95 \%}$ & $\mathrm{HP}$ & $\mathrm{C}_{95 \%}$ & HP & $\mathrm{C}_{95 \%}$ & $\mathrm{HP}$ \\
\hline Iron, $\mathrm{mg} / 1$ & 0.75 & 0.04 & 0.43 & 0.02 & 0.26 & 0.02 & 0.46 & 0.03 \\
\hline Manganese, $\mathrm{mg} / \mathrm{l}$ & 0.02 & 0.003 & 0,02 & 0.004 & 0.02 & 0.003 & 0.03 & 0.01 \\
\hline Nitrates, $\mathrm{mg} / \mathrm{l}$ & 3.58 & 0.001 & 3,36 & 0.001 & 5.38 & 0.002 & 4.90 & 0.002 \\
\hline Cobalt, mg/1 & 0.02 & 0.003 & 0.02 & 0.004 & 0.02 & 0.003 & - & - \\
\hline Magnesium, mg/l & 10.08 & 0.004 & 13.22 & 0.01 & 3.88 & 0.001 & 4.74 & 0.002 \\
\hline Copper, mg/l & 0.02 & 0.003 & 0.02 & 0.003 & 0.011 & 0.002 & 0.04 & 0.006 \\
\hline Fluorine, mg/l & 0.16 & 0.001 & 0.17 & 0,002 & 0.17 & 0.002 & 0.17 & 0.002 \\
\hline Lead, $\mathrm{mg} / 1$ & 0.002 & 0.004 & 0.004 & 0.001 & 0.002 & 0.003 & 0.001 & 0.002 \\
\hline form, $\mathrm{mg} / \mathrm{l}$ & 0.0 & 0.0 & 0.01 & 0.0 & 0.03 & 0.008 & 0.01 & 0.003 \\
\hline Bromdichloromethane, $\mathrm{mg} / \mathrm{l}$ & 0.003 & 0.0 & 0.0 & $1.3 \cdot 10^{-4}$ & 0.004 & 0.002 & 0.003 & 0.002 \\
\hline Strontium & 0.3 & $7.5 \cdot 10^{-5}$ & 0.280 & $7.0 \cdot 10^{-5}$ & 0.010 & $2.5 \cdot 10^{-6}$ & 0.180 & $4.5 \cdot 10^{-5}$ \\
\hline \multicolumn{9}{|c|}{ Results of organoleptic risk assessment } \\
\hline Criteria taken into account & $\mathrm{C}_{\mathrm{m} 98}$ & OP & $\mathrm{C}_{\mathrm{m} 98}$ & $\mathrm{OP}$ & $\mathrm{C}_{\mathrm{m} 98}$ & OP & $\mathrm{C}_{\mathrm{m} 98}$ & $\mathrm{OP}$ \\
\hline Color, $^{\circ}$ & 14.4 & 0.01 & 11.5 & 0.01 & 14.1 & 0.01 & 15.9 & 0.01 \\
\hline Turbidity, mg/l & 7.76 & 0.14 & 3.15 & 0.01 & 4.0 & 0.02 & 3.92 & 0.02 \\
\hline $\mathrm{pH}$, unit & $7.71^{*}$ & 0.005 & $7.55^{*}$ & 0.003 & $7.0 *$ & 0.001 & $7.31 *$ & 0.001 \\
\hline Iron, 1 & 1.74 & 0.7 & 0.97 & 0.38 & 0.5 & 0.13 & 1.01 & 0.4 \\
\hline ese, $\mathrm{mg} / \mathrm{l}$ & 0.02 & $1.9 \cdot 10^{-5}$ & 0.05 & $2.0 \cdot 10^{-3}$ & 0.04 & $7.9 \cdot 10^{-4}$ & 0.06 & $3.6 \cdot 10^{-3}$ \\
\hline \multicolumn{9}{|c|}{ Cancerogenic risk assessment results } \\
\hline Criteria taken into account & $\mathrm{C}_{95 \%}$ & КР & $\mathrm{C}_{95 \%}$ & KP & $\mathrm{C}_{95 \%}$ & КР & $\mathrm{C}_{95} \%$ & КР \\
\hline Lead, mg/l & 0.002 & $1.2 \cdot 10^{-6}$ & 0.004 & $2.2 \cdot 10^{-6}$ & 0.002 & $8.7 \cdot 10^{-7}$ & 0.001 & $7.4 \cdot 10^{-7}$ \\
\hline Chloroform, $\mathrm{mg} / \mathrm{l}$ & 0.01 & $9.2 \cdot 10^{-7}$ & 0.01 & $7.7 \cdot 10^{-7}$ & 0.03 & $1.9 \cdot 10^{-6}$ & 0.01 & $8.1 \cdot 10^{-7}$ \\
\hline Bromdichloromethane, $\mathrm{mg} / \mathrm{l}$ & 0.003 & $2.4 \cdot 10^{-6}$ & 0.002 & $1.8 \cdot 10^{-6}$ & 0.004 & $2.8 \cdot 10^{-6}$ & 0.003 & $2.2 \cdot 10^{-6}$ \\
\hline
\end{tabular}

N o t e s:

$\mathrm{C}_{\mathrm{m} 98}$ - maximum concentrations of $98 \%$ probability;

$\mathrm{C}_{95 \%}$-average annual concentrations of $95 \%$ probability;

«-»- cobalt concentration less than test sensitivity threshold (less than $0.01 \mathrm{mg} / \mathrm{l}$ );

* - average value for hydrogen indicator is taken.

Carcinogenic risks to public health from exposure to chemicals from the drinking water supplied to the distribution network did not exceed the acceptable level (0.00001) both for the indices considered separately and for their cumulative effect.

According to the data of the integrated assessment for the drinking water quality from the distribution network, it was found that for all objects the overall indices did not correspond to the permissible value, which is associated with exceeding the levels of acceptable risk for olfactor-reflex effects (for all residential settlements) and non-carcinogenic risk (for KET).

The deterioration pattern of the drinking water quality from the centralized water supply systems for population, is caused by the chemical composition, affecting mainly its organoleptic properties and is widespread $[19,20]$. In general, the chemical composition of the drinking water studied does not pose a threat to public health, however, it is necessary to reconstruct water supply systems and correct the lack of macro- and microelements in drinking water through additional sources of their supply, including food and food additives.

\section{Conclusions:}

- the sanitary-epidemiological assessment of water from the centralized household and drinking water supply systems on the Island Russkiy showed that the highest contribution to the water quality is made by the non- 
compliance with hygienic norms for organoleptic parameters in terms of iron and turbidity, as well as microbiological indices;

- it was shown that deterioration of the drinking water quality occurs in the process of its transportation from water pumping station to disposable device;

- calculation of an overall index for the drinking water of the centralized household and drinking water supply systems in terms of chemical harmlessness allowed for differentiation the water hygienic quality by settlements;

- the non-carcinogenic risks from total exposure to substances exceeded the permissible values in one of the centralized water supply systems owing to total iron;

- the carcinogenic health risks for population from the exposure to chemicals from the drinking water supplied to the distribution network did not exceed the permissible level both for certain indices considered separately, as well as for their total impact;

- in order to improve the sanitary reliability of the centralized water supply systems, it is necessary to reconstruct water supply systems in the Island Russkiy, which will give an opportunity to preserve the composition consistency of the natural water from the source to the point of consumption;

- physiological ill-being of water detected should be adjusted with food and nutritional additives to meet the average daily requirement of a body for macro- and microelements.

Funding. The research was not granted any sponsor support.

Conflict of interests. The authors declare there is no any conflict of interests.

\section{References}

1. Savel'ev S.I., Trukhina G.M., Bondarev V.A., Nakhichevanskaya N.V. Development of social and hygienic monitoring at the regional level. Gigiena $i$ sanitariya, 2016, vol. 95, no. 11, pp. 1033-1037 (in Russian).

2. Zaitseva N.V., May I.V., Kir'yanov D.A., Goryaev D.V., Kleyn S.V. Social and hygienic monitoring today: state and prospects in conjunction with the risk-based supervision. Health Risk Analysis, 2016, no. 4, pp. 4-16. DOI: 10.21668/health.risk/2016.4.01.eng

3. Meshkov N.A., Val'tseva E.A., Baeva Yu.I., Krylitsyna E.A. Assessment the conditionality of samara city population incidence under the influence of environmental factors. Izvestiya Samarskogo nauchnogo tsentra Rossiiskoi akademii nauk, 2017, vol. 19, no. 2 (2), pp. 300-306 (in Russian).

4. Mironenko O.V., Kiselev A.V., Noskov S.N., Pan'kin A.V., Magomedov Kh.K., Shengeliya Z.N., Myakisheva S.N. Prognosis of morbidity and health risk assessment during hygienic research associated with of chemical impact. Vestnik Sankt-Peterburgskogo universiteta. Seriya 11. Meditsina, 2017, vol. 12, no. 4, pp. 419-428 (in Russian).

5. Chen Z., Kahn M.E., Liu Y., Wang Z. The consequences of spatially differentiated water pollution regulation in China. Journal of Environmental Economics and Management, 2018, vol. 88, pp. 468-485. DOI: 10.1016/j.jeem.2018.01.010

6. Fedorov V.N., Zibarev E.V., Novikova Yu.A., Kovshov A.A., Fridman K.B., Slyusareva O.V. Hygienic assessment of health risk factors for population of megapolisis' satellite towns by the example. Gigiena i sanitariya, 2017, vol. 96, no. 7, pp. 614-619 (in Russian).

7. Ahmed F., Mishra V. Estimating relative immediacy of water-related challenges in Small Island Developing States (SIDS) of the Pacific Ocean using AHP modeling. Modeling Earth Systems and Environment, 2017, no. 6, pp. 201-214. DOI: 10.1007/s40808-019-00671-2

8. Qasemi M., Farhang M., Biglari H., Afsharnia M., Ojrati A., Khani F., Zarei A. Health risk assessments due to nitrate levels in drinking water in villages of Azadshahr, northeastern Iran. Environ Earth Sci, 2018, vol. 77, no. 23, pp. 78-82. DOI: 10.1007/s12665-018-7973-6

9. Stevanovic S., Nikolic M., Deljanin Ilic M. Calcium and Magnesium in Drinking Water as Risk Factors for Ischemic Heart Disease. Polish Journal of Environmental Studies, 2017, vol. 26, no. 4, pp. 1673-1680. DOI: $10.15244 /$ pjoes/68563

10. Jiang L., He P., Chen J., Liu Y., Liu D., Qin G., Tan N. Magnesium levels in drinking water and coronary heart disease mortality risk: a meta-analysis. Nutrients, 2016, vol. 8, no. 1, pp. 5-13. DOI: $10.3390 /$ nu8010005 
11. Chao S., Fan J., Wang L. Association between the levels of calcium in drinking water and coronary heart disease mortality risk: Evidence from a meta-analysis. International Journal of Clinical and Experimental Medicine, 2016, vol. 9, no. 9, pp. 17912-17918.

12. Arvin E., Bardow A., Spliid H. Caries affected by calcium and fluoride in drinking water and family income. Journal of water and health, 2018, vol. 16, no. 1, pp. 49-56. DOI: 10.2166/wh.2017.139

13. Yani R.W.E., Palupi R., Bramantoro T., Setijanto D. Analysis of Calcium Levels in Groundwater and Dental Caries in the Coastal Population of an Archipelago Country. Open Access Macedonian journal of medical sciences, 2019, vol. 7, no. 1, pp. 134-138. DOI: 10.3889/oamjms.2019.013

14. Kiku P.F., Kislitsyna L.V., Bogdanova V.D., Sabirova K.M. Risk assessment sanitarychemical indicators of water for the population of the Khasan district in Primorsky krai. Ekologiya cheloveka, 2018, no. 6, pp. 12-17 (in Russian).

15. Tafeeva E.A. The sanitary and epidemiological assessment of centralized drinking water supply on the territory of oil-producing areas of the republic of Tatarstan. Sovremennye problemy nauki $i$ obrazovaniya, 2015, no. 6, pp. 79-85 (in Russian).

16. Tulakin A.V., Tsyplakova G.V., Ampleeva G.P., Kozyreva O.N., Pivneva O.S., Trukhina G.M. Regional problems of the provision of hygienic reliability of drinking water consumption. Gigiena $i$ sanitariya, 2016, vol. 95, no. 11, pp. 1025-1028 (in Russian).

17. Pierce G., Gonzalez S.R., Roquemore P., Ferdman R. Sources of and solutions to mistrust of tap water originating between treatment and the tap: Lessons from Los Angeles County. Science of the Total Environment, 2019, vol. 1, no. 694, pp. 1336-1346. DOI: 10.1016/j.scitotenv.2019.133646

18. Baig S.A., Lou Z., Baig M.A., Qasim M., Shams D.F., Mahmood Q., Xu X. Assessment of tap water quality and corrosion scales from the selected distribution systems in northern Pakistan. Environmental monitoring and assessment, 2017, vol. 189, no. 4, pp. 194. DOI: 10.1007/s10661-017-5907-5

19. Fedorov V.N., Tikhonova N.A., Zaitsev O.B., Myasnikov I.O. Opyt soglasovaniya vremennykh otklonenii ot gigienicheskikh normativov kachestva pit'evoi vody [Experience in agreeing upon temporary deviations of drinking water quality from hygienic standards]. Zdorov'e - osnova chelovecheskogo potentsiala: problem i puti ikh resheniya, 2019, vol. 14, no. 1, pp. 359-365 (in Russian).

20. Liu G., Zhang Y., Knibbe W.J., Feng C., Liu W., Medema G. Potential impacts of changing supply-water quality on drinking water distribution: A review. Water research, 2017, vol. 1, no. 116, pp. 135-148. DOI: 10.1016/j.watres.2017.03.031

Bogdanova V.D., Kiku P.F., Kislitsyna L.V. Hygienic assessment of drinking water from underground water sources taken from centralized water supply systems on island Russkiy. Health Risk Analysis, 2020, no. 2, pp. 28-37. DOI: 10.21668/health.risk/2020.2.03.eng

Received: 18.03 .2020

Accepted: 02.06.2020

Published: 30.06 .2020 